\title{
SUSTAINABLE DECOMMISSIONING AND INTEGRATED CLOSURE PLANNING OF SELECTED MINE SITES IN THE BICOL REGION, PHILIPPINES
}

\author{
AMELIA B. GONZALES* \\ Bicol University College of Engineering, East Campus, Legazpi City, Albay 4500, Philippines \\ *Corresponding author: abbg0116@yahoo.com
}

\begin{abstract}
The study assessed the status of the Rapu-Rapu Minerals, Incorporated (RRMI) and the Filminera Resources Corporation (FRC) which are the polymetallic and mineral mining sites, respectively in the Bicol Region, Philippines regarding their mine closure and decommissioning procedures in relation to the impact communities that they engaged. It is in this context that the study was implemented to set a management direction in the inevitable event of mine closure and decommissioning. The study utilized the qualitative and quantitative methods of research. Respondents consisted of the key officials of government agencies and municipal and barangay officials as well as households of the host and impact communities covering the two mining sites of Rapu-Rapu and Aroroy as well as community organizations and mining company representatives. Findings showed that both mining sites extract similar resources and have been paying taxes to the Philippine government. Although the RRMI has initiated its mine closure process, decommissioning is underway and still needs to undergo its standard procedure with various stakeholders, while FRC has its operations ongoing. It is recommended that mine closure planning must be integrated within the overall mine operations plan, and should be integral to the operational life cycle of the mine sites.
\end{abstract}

Keywords: integrated closure planning; sustainable decommissioning

\section{Introduction}

The Philippine mining industry had a long mining history beginning with the Spanish colonial period. The first recorded corporate mining activity began in 1902 during the American colonial period in Northern Philippines. Historically, mining has been associated with the plunder of other natural resources such as forest resources because of the need for timber in underground mines. The Philippine mining industry enjoyed a boom in the 1960s and 1970s when the country became the world's 7th largest producer of gold and 10th largest producer of copper. However, the industry suffered a decline from the 1980s. When the Mining Act of 1995 was passed into law, a slight spike in equity investments occurred. However, strong opposition from the Church and civil society organizations created uncertainties among investors. In 2000-2004, the mining sector's contribution to exports declined to 1.7 percent annually (Risk Asia Consulting 2006).

Mining industries in the Philippines is one of the biggest contributors in government's revenue (taxes) yet it cannot also be denied that it has caused long term environmental alteration and degradation as well as social impact which are evident once mine site operations have ceased (Limpitlaw 2004). This could be the result of mining legislation which failed to prevent or minimize the possible long-term effects on the environment on account of the mining operations and mine closure (Dalupan 2001). It should be noted that the Philippines is not unique to this predicament as some of the international mining community faces similar problems, particularly in the mineral and polymetallic industry. Most marginal mines worldwide have closed and never to be re-opened.
In the Philippines, the number of operating mines has declined overall to a low of 25 today. This trend is particularly noteworthy because it clearly shows that while the mining industry in the Philippines declined, it has done so at a time of increased worldwide investment in exploration and mining elsewhere in the Asia Pacific region. This has been particularly true in Papua New Guinea and Indonesia. The number of abandoned non-operating mines has increased by 83 percent whereas the number of explored prospects and under development exploration properties has declined by 50 percent. The number of abandoned/non-operating mines is at a high and the number of explored prospects and those under development/exploration is at an all-time low. Hence, mine closure planning is very significant, which is a practice but is neither complete nor formalized for a large majority of companies (Peck 2005).

On this premise, the study was designed to assess the Rapu-Rapu Minerals, Incorporated (RRMI) which implements the Rapu-Rapu Polymetallic Project (RRPP) being managed by the Korea Malaysia Philippines Resources (KMPRI) and the Masbate Gold Project being managed by the Filminera Resources Corporation (FRC) mining sites in the Bicol Region with the hope of recommending policies for the sustainable decommissioning and integrated closure of mineral and polymetallic mining operations. Specifically, it seeks to find answers to the following objectives: (1) determine the status of mineral and polymetallic mines under study in terms of operational, economic and social aspects; (2) determine the views of stakeholder and community involvements in the decommissioning and planning phase towards mine closure; (3) identify closure legislation and policies to regulate the implementation of sustainable mine de- 
commissioning and closure practices; and (4) determine mining policies that may be recommended to ensure a sustainable decommissioning and closure of mineral and polymetallic mining operations in the Bicol Region.

\section{Materials and Methods}

The study was conducted in the municipalities of Rapu-Rapu and Aroroy, Albay and Masbate, Philippines. Specific study sites are the three direct impact barangays Binosawan, Malobago and Pagcolbon and three indirect impact barangays, namely Linao, Sta. Barbara and Tinopan. In Aroroy, Masbate, the barangays of Amoroy, Bangon, Puro, Syndicate, Panique, Capsay, Balawing, and Lanang are the direct impact area without any designated indirect impact barangays.

Desk reviews, field observations and qualitative and quantitative approaches in data collection was used. Both secondary and primary data sources were used. The primary data was obtained from a survey of selected households and key informant interviews (KII) of different stakeholders. The purposive sampling through a non-random technique in obtaining data was used which involved the identification and selection of individuals as participants due to certain qualities they pos- sess. These qualities or criteria for their selection covered the tenure of their stay as common residents of at least 15 years, who willingly provided the information by virtue of their knowledge and experience, availability and willingness to participate, and the ability to communicate experiences or opinions in an articulate, expressive, and reflective manner. The respondents were either ordinary resident and/or are employees of the mining company.

The survey questionnaire used consisted of two parts; the first part covered the socio-demographic information, and the second part, dealt with the level of stakeholders' community involvement in the planning and operating procedure towards mine closure and decommissioning. A total of 30 randomly selected respondents per municipality, with a total of 60 respondents across areas were surveyed covering both direct and indirect impact barangays of the two mine sites to gather information. A total of 30 key informants which include two consultants, eight key officials of the mine company, 20 informants from direct and indirect impacts municipalities and barangay officials.

Secondary data sources include information from the attached agencies of the Department of Environment and Natural Resources (DENR) Regional Office No. 5 such as the Environment Management Bureau (EMB), the Mines and Geosciences (MGB), and the Office of

Table 1 Description of mining project during operation phase.

\begin{tabular}{|c|c|c|}
\hline Basic Description & Rapu-Rapu Minerals Incorporated (MMRI) & Filminera Resources Corporation (FRC) \\
\hline Location & Rapu-Rapu, Albay & Aroroy, Masbate \\
\hline $\begin{array}{l}\text { Geographic } \\
\text { coordinates }\end{array}$ & $13^{\circ} 10^{\prime} 27^{\prime \prime} \mathrm{N} / 121^{\circ} 12^{\prime} 27^{\prime \prime} \mathrm{E}$ & $12^{\circ} 28^{\prime} 4^{\prime \prime} \mathrm{N} / 123^{\circ} 23^{\prime} 46^{\prime \prime} \mathrm{E}$ \\
\hline Tenement & $\begin{array}{l}\text { Mineral sharing production agreement and mining patents } \\
\text { approved in 1998, } 2000 \text { and } 2004 \text { with an area } \\
\text { of 4,663 hectares }\end{array}$ & $\begin{array}{l}\text { Mineral sharing production agreement }-289.9466 \text { hectares; } \\
\text { mining lease contract - } 108 \text { has. and patented mining claims } \\
-236 \text { has. in } 1997 .\end{array}$ \\
\hline Tenement Holder & Rapu-rapu minerals incorporated (MMRI) & Filminera resources corporation (FRC) \\
\hline $\begin{array}{l}\text { Permits Approval/ } \\
\text { Secured }\end{array}$ & Partial declaration of mining project feasibility study & Declaration of mining feasibility in 2006 \\
\hline Major Stakeholder & $\begin{array}{l}\text { Lafayette NL represented by Roderick Watt - country } \\
\text { manager }\end{array}$ & $\begin{array}{l}\text { Thistle mining Corp. Canada/South Africa Gerri Maritz } \\
\text { Kennedy/Andreas Johannes Graetz }\end{array}$ \\
\hline Foreign Partners & Lafayette NL Australia, LG Collins and KORES of South Korea & B2Gold Corporation of Canada \\
\hline Commodity & Copper, gold, silver and zinc & Chromite, copper, gold, nickel and silver \\
\hline $\begin{array}{l}\text { Geology and Min- } \\
\text { eralization }\end{array}$ & $\begin{array}{l}\text { Project area is underlain by schist that contain massive } \\
\text { polymetallic sulphides consisting mainly of pyrite, with } \\
\text { lesser amounts of chalcopyrite and sphalerite }\end{array}$ & $\begin{array}{l}\text { Gold deposits are centred on a northwest-to-south east } \\
\text { mineralized volcanic belt, } 5-7 \mathrm{~km} \text { wide, bounded by two } \\
\text { northwest-trending fault zones }\end{array}$ \\
\hline Reserves & $\begin{array}{l}\text { Project has a reserve of about } 5.9 \text { Million MT @ 1.2\% Cu; } \\
2.5 \mathrm{~g} / \mathrm{t} \mathrm{Ag} \mathrm{\&} 2.1 \% \mathrm{Zn}\end{array}$ & $\begin{array}{l}48,000,000 \mathrm{MT} @ 1.30 \mathrm{~g} / \mathrm{t} \text { Au with a gross value of US\$ } 738 \mathrm{mil}- \\
\text { lion }\end{array}$ \\
\hline Production Rate & $\begin{array}{l}\text { Annual production rate is placed at } 10,000 \mathrm{MT} \text { for } \mathrm{Cu} ; \\
50,000 \mathrm{oz} \text {. for } \mathrm{Au} ; 14,000 \mathrm{MT} \text { for } \mathrm{Zn} \text { and } 60,000 \mathrm{oz} \text {. for } \mathrm{Ag}\end{array}$ & $\begin{array}{l}\text { Daily production of } 17,123 \mathrm{t} \text { milled. Mine produced } \\
155,000 \mathrm{oz} \text {. Au in } 2012 \text { and to produce } 200,000 \mathrm{oz} \text {. Au in } 2013\end{array}$ \\
\hline Mine Life & Estimated at 7 years & Estimated at 12 years \\
\hline Financial Details & $\begin{array}{l}\text { Estimated to have a potential investment of US\$ } \$ 2 \text { million } \\
\text { and potential gross sales of US\$ } 41 \text { million/year. Potential } \\
\text { estimated at US\$ } 0.80 \text { million/year Excise tax due to the } \\
\text { Philippine government (without incentives) and Potential } \\
\text { Income Tax of US\$ } 5.7 \text { Million/year (without incentives) }\end{array}$ & $\begin{array}{l}\text { Potential investment US\$ } 45 \text { million and potential gross } \\
\text { sales US\$ } 62 \text { million per year. Potential Excise Tax due to the } \\
\text { Philippine government US\$ } 1.2 \text { million per year (without } \\
\text { incentives) and Potential Income Tax US\$ } 7 \text { million per year } \\
\text { (without incentives) }\end{array}$ \\
\hline $\begin{array}{l}\text { Potential } \\
\text { Employment }\end{array}$ & 1,000 during construction and 274 during operation & 2,500 during construction and 300 during operation \\
\hline
\end{tabular}

Source: Mines and Geosciences Bureau - DENR. 
Municipal Planning and Development (MPDO) in the Municipalities of Aroroy, Masbate and Rapu-Rapu, Albay. Descriptive statistics such as frequency count and arithmetic mean were employed to analyse the relevant datasets.

\section{Results and Discussions}

\section{Operational, economic and social status in the project site}

The information on the status of the mine sites in terms of operation was acquired from the Mines and Geosciences Bureau (MGB) of the Department of Environment and Natural Resources (DENR) Regional Office V. Table 1 presents the basic descriptions of the two mining projects on their operational stage.

Findings showed that both mining companies extract similar mineral resources such as copper, silver and gold that employs the same methods of extraction which is the open pit mining to extract the ore at a maximum annual rate of one million tons and contributed greatly to the employment and economic wellbeing of the people. However, in terms of mine life, RRMI is at the closures stage while FRC is still on its commercial operations.

The production data of RRMI covering the period CY 2012 to 2013 is presented in Table 2. The company produced 82,533.58 dry metric tons (DMT) of copper concentrate valued at $\mathrm{P} 3,059,559,085.36$ over a period of two years (2012-2013); 55,254.41 DMT of zinc concentrate with a value of $\mathrm{P} 1,333,839,457.21 ; 1,875.34 \mathrm{~kg}$ of Gold valued at P 3,838,878,808.16 and 27,912.18 of Silver valued at P 853,103,301.99. It should be noted that the end of the mine life for RRPP was November 16,2013 . It can be gleaned from the data that apart from copper, there was a decrease in terms of production for the year 2013 for the other minerals compared to year 2012 production.

Table 2 Production of RRMI, CY 2012-2013.

\begin{tabular}{|l|c|r|r|}
\hline Commodity & $\begin{array}{c}\text { Unit of } \\
\text { Measure }\end{array}$ & $\begin{array}{c}\text { Quantity } \\
\text { (kg) }\end{array}$ & $\begin{array}{c}\text { Estimated Value } \\
\text { (Pesos) }\end{array}$ \\
\hline copper concentrate & & & \\
\hline 2012 & DMT & $38,312.77$ & $1,547,378,215.91$ \\
\hline 2013 & DMT & $44,220.81$ & $1,512,180,869.45$ \\
\hline Total & & $\mathbf{8 2 , 5 3 3 . 5 8}$ & $\mathbf{3 , 0 5 9 , 5 5 9 , 0 8 5 . 3 6}$ \\
\hline zinc concentrate & & & \\
\hline 2012 & DMT & $27,871.77$ & $670,914,208.73$ \\
\hline $2013^{*}$ & DMT & $27,382.64$ & $662,925,248.48$ \\
\hline Total & & $\mathbf{5 5 , 2 5 4 . 4 1}$ & $\mathbf{1 , 3 3 3 , 8 3 9 , 4 5 7 . 2 1}$ \\
\hline gold (by-product of copper) & & \\
\hline 2012 & $\mathrm{~kg}$ & 990.77 & $2,128,424,996.11$ \\
\hline 2013 & $\mathrm{~kg}$ & 884.57 & $1,710,453,812.05$ \\
\hline Total & & $\mathbf{1 , 8 7 5 . 3 4}$ & $\mathbf{3 , 8 3 8 , 8 7 8 , 8 0 8 . 1 6}$ \\
\hline $\begin{array}{l}\text { silver } \\
\text { (by-product of copper and zinc) }\end{array}$ & & \\
\hline
\end{tabular}

\begin{tabular}{|l|c|c|c|}
\hline 2012 & $\mathrm{~kg}$ & $17,308.95$ & $549,934,247.74$ \\
\hline 2013 & $\mathrm{~kg}$ & $10,603.23$ & $303,169,054.25$ \\
\hline Total & & $27,912.18$ & $853,103,301.99$ \\
\hline
\end{tabular}

Source: Mines and Geosciences Bureau - DENR.

In the case of the FRC/Philippine Gold Processing and Refining Corporation, production is limited to two most important mineral resources; gold and silver during the study period (2012-2014) (Table 3). A total of $17,057.31 \mathrm{~kg}$ of gold valued at Php 34,028,348,876.40 and $12,545.35 \mathrm{~kg}$ of silver valued at Php 431,663,769.50 were produced from year 2012-2014. It is noteworthy to mention that the gold produced in terms of volume is within the not more $5,000 \mathrm{kgs}(5,499.97-5,949.29)$. However, there was a slight decline for silver in terms of production from 4,514.44 kg and 4,213.37 kg in 2012 and 2013 , respectively to about $3,817.54 \mathrm{~kg}$ in 2014 . This in turn has also dropped a bit in terms of its estimated value from Php 190,659,125.53 in 2012 to Php 103,411,807.91 in 2014 (Table 3).

Table 3 Production of FRC/PGPRC, CY 2012-2014.

\begin{tabular}{|l|c|r|r|}
\hline Commodity & $\begin{array}{c}\text { Unit } \\
\text { of Measure }\end{array}$ & Quantity (kg) & $\begin{array}{c}\text { Estimated value } \\
\text { (Pesos) }\end{array}$ \\
\hline gold & & & \\
\hline 2012 & $\mathrm{~kg}$ & $5,949.29$ & $13,418,662,378.90$ \\
\hline 2013 & $\mathrm{~kg}$ & $5,499.97$ & $10,518,224,761.09$ \\
\hline 2014 & $\mathrm{~kg}$ & $5,608.05$ & $10,091,461,736.41$ \\
\hline Total & & $\mathbf{1 7 , 0 5 7 . 3 1}$ & $\mathbf{3 4 , 0 2 8 , 3 4 8 , 8 7 6 . 4 0}$ \\
\hline silver & & & \\
\hline 2012 & $\mathrm{~kg}$ & $4,514.44$ & $190,659,125.53$ \\
\hline 2013 & $\mathrm{~kg}$ & $4,213.37$ & $137,592,836.06$ \\
\hline 2014 & $\mathrm{~kg}$ & $3,817.54$ & $103,411,807.91$ \\
\hline Total & & $\mathbf{1 2 , 5 4 5 . 3 5}$ & $\mathbf{4 3 1 , 6 6 3 , 7 6 9 . 5 0}$ \\
\hline
\end{tabular}

Source: Mines and Geosciences Bureau - DENR.

Based from the monthly project update report of RRMI and FRC, huge amount of taxes were contributed by both mining companies. For instance, from 2012 to 2014, RRMI contributed to the Philippine government a total revenue of Php 1,003,084,002.45, both in the national and local taxes, while FRC contributed a total amount of Php 2,403,093,440.08 from both national and local taxes for the past three-year duration. This is in accordance with the government share allocated in accordance with Sections 290 and 292 of Republic Act No. 7160 otherwise known as the Local Government Code of 1991. Specifically, the share of local government units (LGUs) in the proceeds in the national taxes shall be forty percent $(40 \%)$ of the gross collection derived by the national government from the preceding fiscal year from mining taxes, royalties, forestry and fishery charges, and such other taxes, fees, or charges, including related surcharges, interests, or fines, and from its share in any co-production, joint venture or production sharing agreement in 
the utilization and development of the national wealth within their territorial jurisdiction, in addition to the internal revenue allotment per Sec 290 of RA. 7160. On the other hand, Section 285 of RA. 7160, stipulates that the internal revenue allotment shall be collected in the following manner (a) Provinces - 23\%; (b) Cities - 23\%; (c) Municipalities - 34\%; and (d) Barangays - 20\%. This shall be determined on the basis of the following formula: (a) Population - 50\%; (b) Land Area - 25\%); and (c) Equal sharing $-25 \%$.

Despite the huge amount of taxes from the share of the government's revenue taxes, it appears that the general economic condition in the host communities are still low. Although the RRMI, it has contributed to the employment of more or less $21.5 \%(3,413)$ to the local population in 2010, while FRC contributed employment to about $8.13 \%(14,927)$ of the local population in the same year, the socio-economic development in the mine sites appears to be problematic. For instance, in RRMI impact barangays, one in ten persons finished grade school and three out of ten are elementary undergraduates. Seven out of 100 graduated from high school and three out of 100 have graduated and earned academic degrees from college. The drop-out rate from elementary to high school is estimated at 90\%. The Rapu-Rapu National High School in Barangay Poblacion is the only accessible secondary school in the island. Survey result attributes the high incidence of poverty and the absence of an accessible secondary school in the area as the culprit. As such, it deprives the islanders for better opportunities in the future. The attribution of poverty incidence is supported by the report of National Statistical Coordination Board (NSCB) that poverty incidence in mining areas is generally higher than the national mean (of 24.7 percent) as of 2003. As a matter of fact, the top most gold and copper producing provinces of the country, namely, Camarines Norte, Masbate and Agusan, are among the areas with highest poverty levels in the country. In addition, World Bank and International Finance Corporation (2002) as cited by SEPO (November 2005) reported that mining has contributed very little to the alleviation of poverty. It should be noted that proceeds from the share of LGUs' should be appropriated by their respective Sanggunian to finance local government and livelihood projects. From these observations, it could be inferred that the share of LGUs has not been appropriated properly and the capacity of LGU in implementing poverty program is weak, in particular in to reducing the problem in education to the minimum.

In FRC host barangays, nearly half or $48 \%$ have attended or completed elementary education. The high school undergraduates constitute $20 \%$; those who completed secondary education are 10\%; college undergraduates constitute around $4 \%$ and those with academic degrees are only $3 \%$. Apparently, these were attributed to the government's effort that provided complete school facilities from elementary up to college. Aroroy, Masbate is a 1st class municipality in the 2nd District of the prov- ince of Masbate. More females finished college than their male counterparts. It is also interesting to note that in RRMI areas, people put much priority on livelihood benefits, while in FRC areas, health services is given much priority (Kearns and Barnett 1998).

When asked regarding the benefits derived from mining operations, $86.7 \%$ from the RRMI areas claimed that the mining operations have given them livelihood (i.e. fishing paraphernalia, funds for animal raising and farming), $76.7 \%$ health services and $73.3 \%$ claimed to benefit from sponsored social projects. The mining company granted them livelihood assistance as part of the Social Development and Management Program (SDMP) commitment of RRMI to the impact barangays (Table 4). In FRC areas, benefits derived were in the order of health services $(83.3 \%)$, educational benefits $(76.7 \%)$ and income from mining employment $(73.3 \%)$. It is noteworthy to mention that these benefits were those contributed to the respondents and not from the proceeds of the government share collected by LGUs.

When asked whether they are aware of the mine closure in the next three to ten years, results obtained showed that $86.7 \%$ and $70 \%$ of respondents from the both mining site barangays responded positively (Table 5). This is due to the various meetings and consultations conducted by the concern mining company in the impact barangays and through a wider dissemination by word-of-mouth relative to the expected mine closure. Added to this is the fact that the mine is currently on its closure stage, and most of the residents are already aware of this.

Table 4 Benefits derived from mining operations.

\begin{tabular}{|l|c|c|c|c|}
\hline \multirow{2}{*}{ Responses } & \multicolumn{2}{|c|}{ RRMI Barangays } & \multicolumn{2}{c|}{ FRC Barangays } \\
\cline { 2 - 5 } & F & $\%$ & F & $\%$ \\
\hline $\begin{array}{l}\text { Livelihood benefits from } \\
\text { mining company }\end{array}$ & 26 & 86.7 & 19 & 63.3 \\
\hline $\begin{array}{l}\text { Income from work in the } \\
\text { mine site }\end{array}$ & 14 & 46.7 & 22 & 73.3 \\
\hline $\begin{array}{l}\text { Educational benefits for } \\
\text { children }\end{array}$ & 20 & 66.7 & 23 & 76.7 \\
\hline $\begin{array}{l}\text { Health benefits from health } \\
\text { services }\end{array}$ & 23 & 76.7 & 25 & 83.3 \\
\hline $\begin{array}{l}\text { Benefits from sponsored } \\
\text { social projects }\end{array}$ & 22 & 73.3 & 20 & 66.7 \\
\hline
\end{tabular}

$(\mathrm{N}=30$ respondents/mining sites)

\section{Stakeholder's views and community involvements in the decommissioning and planning phase towards mine closure}

In the aspect of stakeholder views and community involvements relative to mine decommissioning and closure planning, various consultations were undertaken in the formulation and preparation of the Social Development and Management Program (SDMP) in the two mining sites. A chi-square test $\left(\chi^{2}=32.42, \mathrm{p}<0.001\right)$ indicated that the respondents' perception on the current mining operations differ in the two locations. Respond- 
ents from FRC barangay more likely to show that the current mining operations provided family's income source while the RRMI respondents perceive it to be the source of community projects. This further validates the situation with RRMI areas as the company has commenced in closing mining operations, where only the social projects on account of the SDMP are the ones benefiting the communities, while income from mining operations are the ones obtained by the residents of FRC barangays.

Table 5 Respondents awareness on mine closure in the next 3 to 10 years.

\begin{tabular}{|l|c|c|c|c|}
\hline \multirow{2}{*}{ Responses } & \multicolumn{2}{|c|}{ RRMI Barangays } & \multicolumn{2}{c|}{ FRC Barangays } \\
\cline { 2 - 5 } & F & \% & F & $\%$ \\
\hline Yes & 26 & 86.7 & 21 & 70 \\
\hline No & 4 & 13.3 & 9 & 30 \\
\hline Total & 30 & 100 & 30 & 100 \\
\hline
\end{tabular}

( $\mathrm{N}=30$ respondents/mining sites)

In RRMI impact barangays, the communities were involved in the formulation of the plans for livelihood and employment as a result of the closure of the mining project. Under the SDMP scheme, fishing implements (i.e. banca, nets and fishing gears) were provided; funding opportunities to implement piggery, poultry and goat raising projects; provision of agricultural inputs for coconut, abaca and vegetable production; organization of cooperatives and the recovery of scrap materials for community projects were also included in the package. It also made possible the provision of water system such as storage tanks and water distribution lines, educational assistance in the form of scholarships for pupils and students, provision of electricity, health services and the conduct of medical missions. The maintenance of road networks, environmental conservation and preservations measures were also part of the major provisions of the SDMP for the impact barangays. These are the social services which people source out on account of the mining operations, which is why for them these things are very favourable as, reflected in Table 6.

Comparatively, the SDMP provisions for the FRC impact barangays consists of allocation for environmental safety features with conservation and preservation measures along tailings impounding areas; establishment of community mangrove reforestation and aquaculture projects; establishment of cacao plantation; conversion of the current airstrip into a municipal airport; development of ecotourism.

Table 6 Reasons why people favour mining. *

\begin{tabular}{|l|c|c|c|c|}
\hline \multirow{2}{*}{ Responses } & \multicolumn{2}{|c|}{ RRMI/RRPI Barangays } & \multicolumn{2}{l|}{ FRC Barangays } \\
\cline { 2 - 5 } & Frequency & $\%$ & Frequency & $\%$ \\
\hline $\begin{array}{l}\text { Source of social } \\
\text { services for residents }\end{array}$ & 23 & 76.7 & 21 & 70.0 \\
\hline $\begin{array}{l}\text { Source of community } \\
\text { projects }\end{array}$ & 21 & 70.0 & 20 & 66.7 \\
\hline
\end{tabular}

\begin{tabular}{|l|c|c|c|c|}
\hline Source of income & 15 & 50.0 & 23 & 76.7 \\
\hline $\begin{array}{l}\text { Offer business op- } \\
\text { portunities }\end{array}$ & 13 & 43.3 & 19 & 63.3 \\
\hline Source of patronage & 12 & 40.0 & 18 & 60.0 \\
\hline
\end{tabular}

* Multiple Response

In the municipality; conversion of the building facilities inside the FRC compound to a residential area; development of causeway for commercial operation to accommodate cargo of large vessels; development of an agro-forestry site out of the tailings storage and mill facilities; conversion of the mine power plant into an independent power provider; turnover of the management of the division dam to a local cooperative; maintenance of access roads; and the relocation of the church into a new site.

\section{Closure legislation and policies for sustainable mine decommissioning and closure practices}

Mine closure legislation and policies which regulates the implementation of sustainable mine decommissioning and closure practices adopted and implemented by mining companies are clearly stipulated and embedded in the final mine rehabilitation and decommissioning plan (FMRDP). Such plan is in accordance with Republic Act No. 7942 otherwise known as the "Act Instituting a New System of Mineral Resources Exploration, Development, Utilization and Conservation". This act emphasizes that all mineral resources in public and private lands within the territory and exclusive economic zone of the Republic of the Philippines are owned by the State. It shall be the responsibility of the State to promote their rational exploration, development, utilization and conservation through the combined efforts of government and the private sector in order to enhance national growth in a way that effectively safeguards the environment and protect the rights of affected communities. In Section 85 under Chapter XV of this act, it implies that a semi-annual fee to be known as mine wastes and tailings fee is hereby imposed on all operating mining companies in accordance with the implementing rules and regulations. The mine wastes and tailings fee shall accrue to a reserve fund to be used exclusively for payment for damages such as but not limited to rehabilitation of silted farm lands and other areas devoted to agriculture and fishing caused by mining pollution; Administrative Order No. 2010-21, which provides for a Consolidated Department of Environment and Natural Resources (DENR) Administrative Order for the Implementing Rules and Regulations of Republic Act No. 7942, otherwise known as the "Philippine Mining Act of 1995"; DENR Administrative Order 2005-07, which are the "Amendments to Chapter XVIII of DENR Administrative Order 96-40, as amended, providing for the establishment of the Final Mine and Decommissioning Fund"; Administrative Order No. 2010-21, which provides for a Consolidated Department 
of Environment and Natural Resources Administrative Order for the Implementing Rules and Regulations of Republic Act No. 7942, otherwise known as the "Philippine Mining Act of 1995"; DENR Administrative Order 36, Series of 2004, which revises the DENR Administrative Order No. 29, Series of 1992, to further strengthen the implementation of Republic Act 6969 (Toxic Substances and Hazardous and Nuclear Wastes Control Act of 1990) and Prescribing the Use of Procedural Manual; DENR Administrative Order No. 1996-40, as amended, it specifically provides the guidelines on the determination of a post-mining land use and shall adhere to the principle of sustainable development which meets the need of the present without compromising the ability of the future generations to meet their own needs, with the view of improving the total quality of life, both now and in the future.

The development of a sustainable mining industry is dependent on the development of a regulated and controlled responsible mining industry. However, appropriate legislation and policies should be developed to effectively control and regulate mine closure process within the initial mine assessment and approval process (Clark et al. 1998). Based on the findings of the study, it can be construed that the contribution of mining to the overall economy of the two municipalities is relatively small considering the fact that in case of decommissioning and closure, the local community is directly affected. Hence, an equitable sharing mechanism should be developed so that the host communities may have the highest share, a reverse of the present sharing scheme based on RA 7160. Citing data from the Mines and Geosciences Bureau (MGB), the mining sector currently has a 0.7 percent contribution to the country's gross domestic product (GDP) and comprises 5.6 percent of the total exports of the Philippines. One critical use of the mineral accounts is in the analysis for an appropriate fiscal policy considering its small contribution to the economy and the contentious debate on mining and its links with issues on land-use, environment and social acceptability. In terms of the proposed use of mine facilities and equipment's after mine closure and the suggestions for a sustainable mine closure and decommissioning program in the mining sites, Table 7 and Table 8 reflects the respondent's views, respectively.

Table 7 Suggested use of facilities after closure.

\begin{tabular}{|l|c|c|c|c|}
\hline \multirow{2}{*}{ Responses } & \multicolumn{2}{|c|}{ RRMI Barangays } & \multicolumn{2}{c|}{ FRC Barangays } \\
\cline { 2 - 5 } & F & $\%$ & F & $\%$ \\
\hline School complex & 19 & 63.3 & 20 & 66.7 \\
\hline Sports complex & 16 & 53.3 & 15 & 50 \\
\hline Camp site & 21 & 70 & 23 & 76.7 \\
\hline Housing complex & 18 & 60 & 19 & 63.3 \\
\hline $\begin{array}{l}\text { Tourist destination/ } \\
\text { attraction }\end{array}$ & 22 & 73.3 & 24 & 80 \\
\hline
\end{tabular}

( $\mathrm{N}=30$ respondents/mining sites)
Table 8 Suggestions for a sustainable mine closure and decommissioning program.

\begin{tabular}{|l|c|c|c|c|}
\hline \multirow{2}{*}{ Responses } & \multicolumn{2}{|c|}{ RRMI Barangays } & \multicolumn{2}{c|}{ FRC Barangays } \\
\cline { 2 - 5 } & F & $\%$ & F & $\%$ \\
\hline $\begin{array}{l}\text { More participation in } \\
\text { meetings and discussions }\end{array}$ & 20 & 66.7 & 27 & 90 \\
\hline $\begin{array}{l}\text { Clear cut policies are } \\
\text { provided for the program }\end{array}$ & 25 & 83.3 & 26 & 86.7 \\
\hline $\begin{array}{l}\text { Transparency should be } \\
\text { observed in all aspects }\end{array}$ & 24 & 80 & 25 & 83.3 \\
\hline $\begin{array}{l}\text { Facilitate release of funds } \\
\text { for social projects }\end{array}$ & 28 & 93.3 & 29 & 96.7 \\
\hline $\begin{array}{l}\text { Participatory planning } \\
\text { and implementation } \\
\text { of program }\end{array}$ & 27 & 90 & 24 & 80 \\
\hline
\end{tabular}

( $\mathrm{N}=30$ respondents/mining sites)

The expectations from the Local Government Unit (LGU) to achieve a sustainable mine closure and decommissioning plan or mechanism was also asked and majority of the answers of the respondents covering the two mining sites focused on the coordination with various stakeholders, to assist and support the closure planning process and the prioritization of the SDMP projects as reflected in Table 9. Although these were emphasized prior to the FMRDP, some respondents however, may not be familiar of the rightful process for the sustainable closure and decommissioning but are aware of how things can be properly managed.

Table 9 Expectations from LGU to achieve the sustainable mine closure/ decommissioning.

\begin{tabular}{|l|c|c|c|c|}
\hline \multirow{2}{*}{ Responses } & \multicolumn{2}{|c|}{ RRMI Barangays } & \multicolumn{2}{c|}{ FRC Barangays } \\
\cline { 2 - 5 } & F & $\%$ & F & $\%$ \\
\hline $\begin{array}{l}\text { Assist and support the } \\
\text { planning process }\end{array}$ & 15 & 50 & 20 & 66.7 \\
\hline $\begin{array}{l}\text { Asserts that mine company } \\
\text { follows the law }\end{array}$ & 9 & 30 & 12 & 40 \\
\hline $\begin{array}{l}\text { Prioritize SDMP projects } \\
\text { from mining company }\end{array}$ & 18 & 60 & 15 & 50 \\
\hline Participates in the process & 17 & 56.7 & 19 & 63.3 \\
\hline $\begin{array}{l}\text { Coordinates with various } \\
\text { stakeholders }\end{array}$ & 20 & 66.7 & 23 & 76.7 \\
\hline
\end{tabular}

( $\mathrm{N}=30$ respondents/mining sites)

\section{Conclusions and Recommendations}

Assessment result showed that both Rapu-Rapu and Aroroy mining sites are compliant with the provisions of the Philippine Mining Act 1995, wherein both the mining companies follows the prescribed implementing rules and regulations as stipulated on the said Act. Likewise, practices regarding mine closure were adopted by both mining companies which are clearly stipulated and embedded in the final mine rehabilitation and decommissioning plan (FMRDP). However, much has to be desired 
in terms of stakeholder participation and community engagements for sustainability at the start of planning for operations to have a proactive perspective for the future mine decommissioning and closure. In the case of RRMI, while it has complied with the minimum requirements cited in the legal provisions, such are not sustainable in terms of economic and social continuity. This is because, what has been laid down at the outset, prior to the closure phase primarily focused on the SDMP project planning and implementation and not much on the decommissioning aspects. This features how the structures and facilities will be able to serve in favour of the impact communities directly and indirectly affected by mining. Facilities and infrastructures built to support the mining operations is worth millions of pesos, yet lesser community interventions were undertaken to pave way to their involvement, participation and decisions.

It is therefore recommended that the following mining policies to achieve a sustainable decommissioning and closure be made: 1) The development programs as an output of the consultations and legal processes implemented to establish the SDMP of the impact barangays should be integrated as a development roadmap subject of the LGUs for regular review, monitoring and evaluation; 2) Mine closure planning must be integrated within the overall mine operations plan, and should be integral to the operational life cycle of a mine to include: (a) Mine Closure Planning at the feasibility phase of mine operations, which allows mining operations to identify future constraints and costs of mine closure; (b) Financial provisions and assurances; (c) stakeholder engagement and community consultation needs to be integrated within the overall mine operations and closure processes; (d) clear and measurable indicators are needed to track compliance; 3) The organizational transformation of the DENR, specifically the MGB and the EMB of the DENR, where a regulatory structure should be rationalized. Currently, the MGB is under the DENR, as well as the EMB. The research strongly recommends for the creation of another government agency like the Environmental Protection Agency (EPA), where the function of which should focus on the Regulatory, Monitoring and Evaluation of mining and other industries' operations and activities, and for which the EMB should be a part. A specialized Bureau, like a Mining Regulatory Authority, that will regulate mining practices, policies and procedures compliant to the Mining Act of 1995 and other legislative policies and protocols. Consequently, the regulatory body should also employ the services of soil scientists as part of the regulatory functions on hazardous wastes brought about by mining operations, or in close collaboration with, but not limited to, the Bureau of Soils and Water Management and with the Department of Agriculture to help ensure sustainability of resources. These recommendations can be integrated into a manual for the regulatory agencies, like the DENR to ensure sustainability in the mining activities, specifically covering the final mine decommissioning and closure planning.

Future studies on the equitable distribution of taxes paid by the industry to ensure the greatest possible benefit for the host community who in most case suffer from the consequences of environmental alteration and modifications from mining industry is highly recommended. Likewise, study on people's priority must be conducted in host communities to properly determine where to concentrate in terms of the corporate social responsibilities of the mining companies.

\section{REFERENCES}

Clark JC, Clark AL, Naito K (1998) Emerging Mineral Policy and Legislation in the Economic Development of the Central Asian Republics. Resour Policy 24: 115-123.

Dalupan CG (2001) Mining and Sustainable Development: Insights from International Law. http://www.sdsg.org/wp-content /uploads/2010/02/Dundee-MiningSD-Dalupan.pdf.

DENR Administrative Order No. 2010-21. Consolidated Department of Environment and Natural Resources (DENR) Administrative Order for the Implementing Rules and Regulations of Republic Act No. 7942. Section 187: Final Mine Rehabilitation/ Decommissioning Plan or Mine Closure Plan.

DENR Administrative Order No. 2010-21. Consolidated Department of Environment and Natural Resources Administrative Order for the Implementing Rules and Regulations of Republic Act No. 7942. Section 187-B: Establishment of the Final Mine Rehabilitation Decommissioning Fund (FMRDF).

DENR Administrative Order 2005-07. Amendments to Chapter XVIII of DENR Administrative Order 96-40.

DENR administrative Order 36, Series of 2004. DENR Administrative Order No. 29 revision, Series of 1992.

DENR Administrative Order No. 1996-40. Guidelines on the determination of a post mining land use.

Kearns RA, Barnett JR (1998) Consumerist ideology and the symbolic landscapes of private medicine, Health Place 3: 171-180.

Limpitlaw D (2004) Mine Closure as a Framework for Sustainable Development. Sustainable Development Practices on Mine Sites - Tools and Techniques. University of the Witwatersrand 10: $134-145$.

Peck P (2005) Mining for Closure: Policies and Guidelines for Sustainable Mining Practice and Closure of Mines. Environment Security Initiative.

Republic Act No 7160. The Local Government Code of the Philippines.

Republic Act No 7942. An Act Instituting a New System of Mineral Resources Exploration, Development, Utilization and Conservation.

Risk Asia Consulting Inc (2006). Fool's Gold: The false economic promises of the Lafayette mining project in Rapu Rapu. http:// www.greenpeace.org/seasia/ph/Global/seasia/report/2006/6 /fool-s-gold-the-false-economi.pdf.

World Bank and International Finance Corporation (2002). Treasure or Trouble: Mining in Developing Countries. Mining Department World Bank and International Finance Corporation, Washington DC, USA. 